\title{
Recent Understandings of Biology, Prophylaxis and Treatment Strategies for Hypertrophic Scars and Keloids
}

\author{
Ho Jun Lee ${ }^{1}$ (D) and Yong Ju Jang ${ }^{2, *}$ \\ 1 Department of Otorhinolaryngology-Head and Neck Surgery, Chuncheon Sacred Heart Hospital, \\ College of Medicine, Hallym University, Chuncheon 24253, Korea; leehj@hallym.or.kr \\ 2 Department of Otolaryngology, Asan Medical Center, University of Ulsan College of Medicine, \\ Seoul 05505, Korea \\ * Correspondence: jangyj@amc.seoul.kr; Tel.: +82-2-3010-3712
}

Received: 22 November 2017; Accepted: 8 January 2018; Published: 2 March 2018

\begin{abstract}
Hypertrophic scars and keloids are fibroproliferative disorders that may arise after any deep cutaneous injury caused by trauma, burns, surgery, etc. Hypertrophic scars and keloids are cosmetically problematic, and in combination with functional problems such as contractures and subjective symptoms including pruritus, these significantly affect patients' quality of life. There have been many studies on hypertrophic scars and keloids; but the mechanisms underlying scar formation have not yet been well established, and prophylactic and treatment strategies remain unsatisfactory. In this review, the authors introduce and summarize classical concepts surrounding wound healing and review recent understandings of the biology, prevention and treatment strategies for hypertrophic scars and keloids.
\end{abstract}

Keywords: keloid; hypertrophic scar; scar biology; scar prevention; scar treatment

\section{Introduction}

Many life situations result in injury to the skin. Physical trauma, surgical incisions, burn injuries, vaccinations, skin piercings, herpes infection and even insect bites can cause skin injury and resultant scar problems. Each year in the developed world, approximately 100 million people suffer from scar-related issues [1]. Most superficial injuries do not leave significant scars, but deep cutaneous injuries occasionally produce serious problems, hypertrophic scars and keloids [2]. Cosmetic problems, functional problems such as contractures and patients' subjective symptoms including pruritus and pain can cause hypertrophic scars and keloids to dramatically affect patients' quality of life, physical status and psychological health [3]. Hypertrophic scars and keloids are fibroproliferative disorders that result from abnormal wound healing, defined as increased or decreased regulation of certain wound healing processes. Understanding the major mechanisms underlying abnormal wound healing and correcting them will benefit numerous patients, like the wide-spread public health effects of antibiotics in the twentieth century. Many studies on hypertrophic scars and keloids have been reported, and our understanding of these conditions is improving. However, the pathophysiology remains extremely complex. In this review, we introduce and summarize the classical concepts of wound healing and review the recent biological advances in treatment, as well as the manner in which these advances translate into preventive and treatment strategies for hypertrophic scars and keloids. This review included the basic knowledge on scar biology any kind of physician should know and may be appropriate for general physicians rather than scar specialists. 


\section{Methods}

The original articles dealing with the biology, prophylaxis and treatment strategies for hypertrophic scars and keloids were searched and reviewed. PubMed, Web of Science and Cochrane library databases were searched on the keywords: hypertrophic scar OR keloid AND biology; hypertrophic scar OR keloid AND prophylaxis; hypertrophic scar OR keloid AND treatment. Time limits were from 1 January 2010 to the present. In addition, important reference articles from the included articles were also reviewed. Several meta-analysis were also reviewed to estimate the outcome of a certain treatment modality. Duplicates, letters, reviews, hypotheses articles dealing with the fibrotic disorders on internal organs, studies dealing with specific surgical techniques and studies published in a language other than English were excluded. Figure 1 shows the flowchart of the literature search for this review.

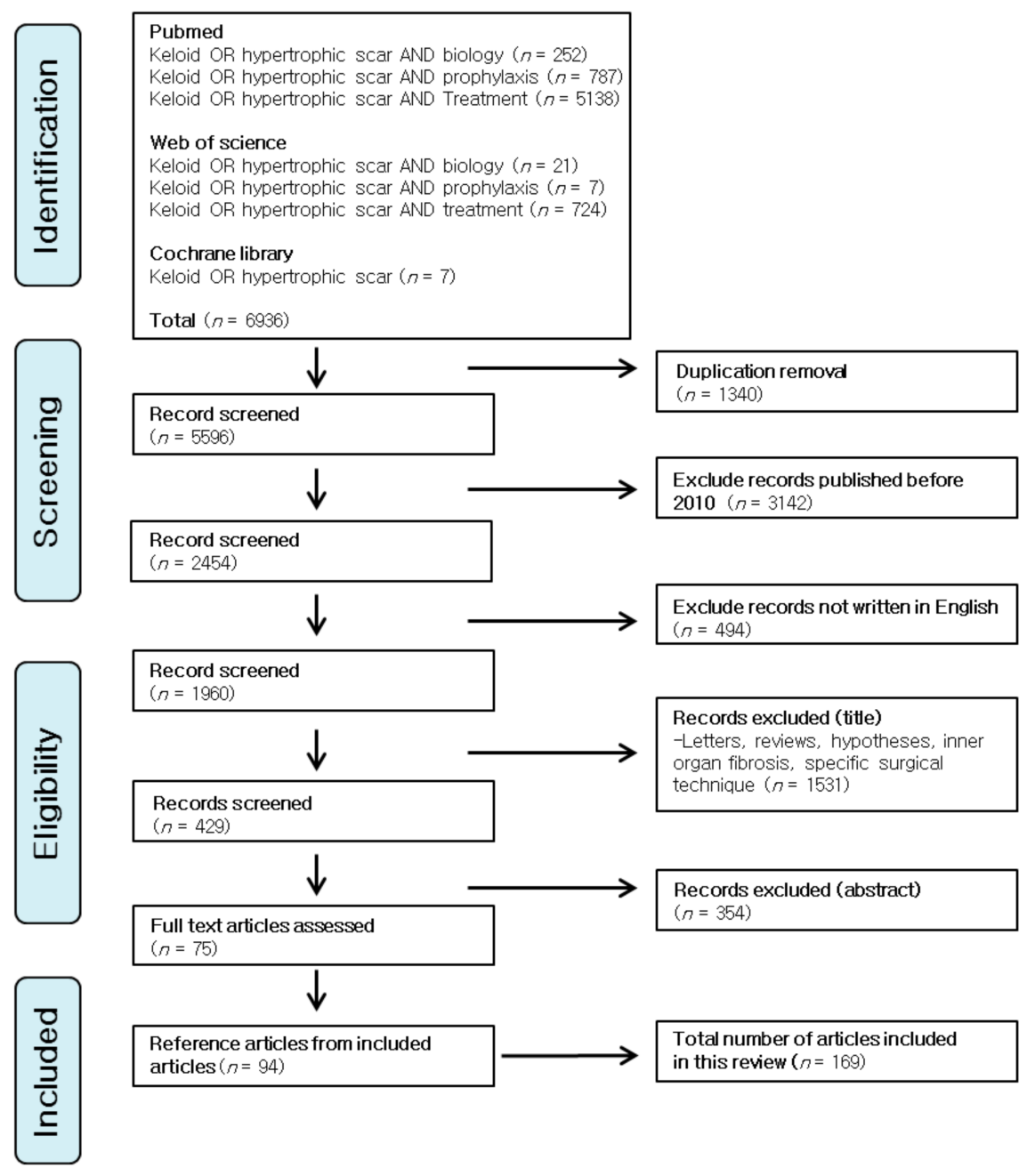

Figure 1. The flowchart of the literature search for this review.

\section{Classical Concepts of Wound Healing}

The classical model of wound healing involves three distinct, but overlapping phases that follow a time sequence: the inflammatory phase, the proliferative phase and the remodeling phase. The first phase of wound healing is the inflammatory phase that starts immediately after tissue injury and lasts for approximately 2-3 days after injury. Coagulation cascades, complement activation and platelet degranulation prevent further fluid and blood losses by creating platelet plugs and a fibrin matrix [4]. The immune system and inflammatory reactions are activated to prevent infection and removing 
devitalized tissues [5]. Neutrophils are recruited by chemotactic factors produced by platelet and bacterial degranulations [6], and monocytes are recruited and differentiated into macrophages 2-3 days after injury.

The second phase of wound healing is the proliferative phase. This phase of new tissue formation occurs approximately 2-3 days after tissue damage and may last for 3-6 weeks. Active cellular proliferation and migration characterize this phase. Keratinocytes migrate to the damaged dermis; new blood vessels grow inward within the damaged tissue; and new capillaries replace the fibrin matrix with granulation tissue via the actions of macrophages and fibroblasts. Granulation tissue forms a new substrate for keratinocyte migration. Keratinocytes proliferate and mature within granulation tissue along the wound margin, restoring the protective function of the epithelium. In the late proliferative phase, a portion of the fibroblasts differentiates into myofibroblasts in association with macrophages. Fibroblasts and myofibroblasts produce extracellular matrix (ECM), mainly in the form of collagen; this accumulated collagen forms most of the eventual scar [7]. Other constituents of ECM include elastin, hyaluronic acids and proteoglycans. Myofibroblasts, which contain actin filaments, have contractile properties and help bring the edges of the wound together over time [8]. Once wound closure is accomplished, the final remodeling phase commences. This phase is characterized by degradation of excessive tissue, transforming immature healing products into a mature form. Remodeling may last for a year or more. Excessive ECM is degraded and remodeled from type III collagen, the main component of ECM present during the early wound healing process, to mature type I collagen.

\section{Important Proteins and Cytokines in the Wound Healing Processes}

It is important to achieve a proper balance between these wound healing phases. Synthesis and degradation of ECM should be balanced, otherwise wound healing may be delayed or result in excessive scars. Important proteins and cytokines that influence balanced wound healing processes are summarized herein (Figure 2) and are important for understanding current investigations in keloid treatment.

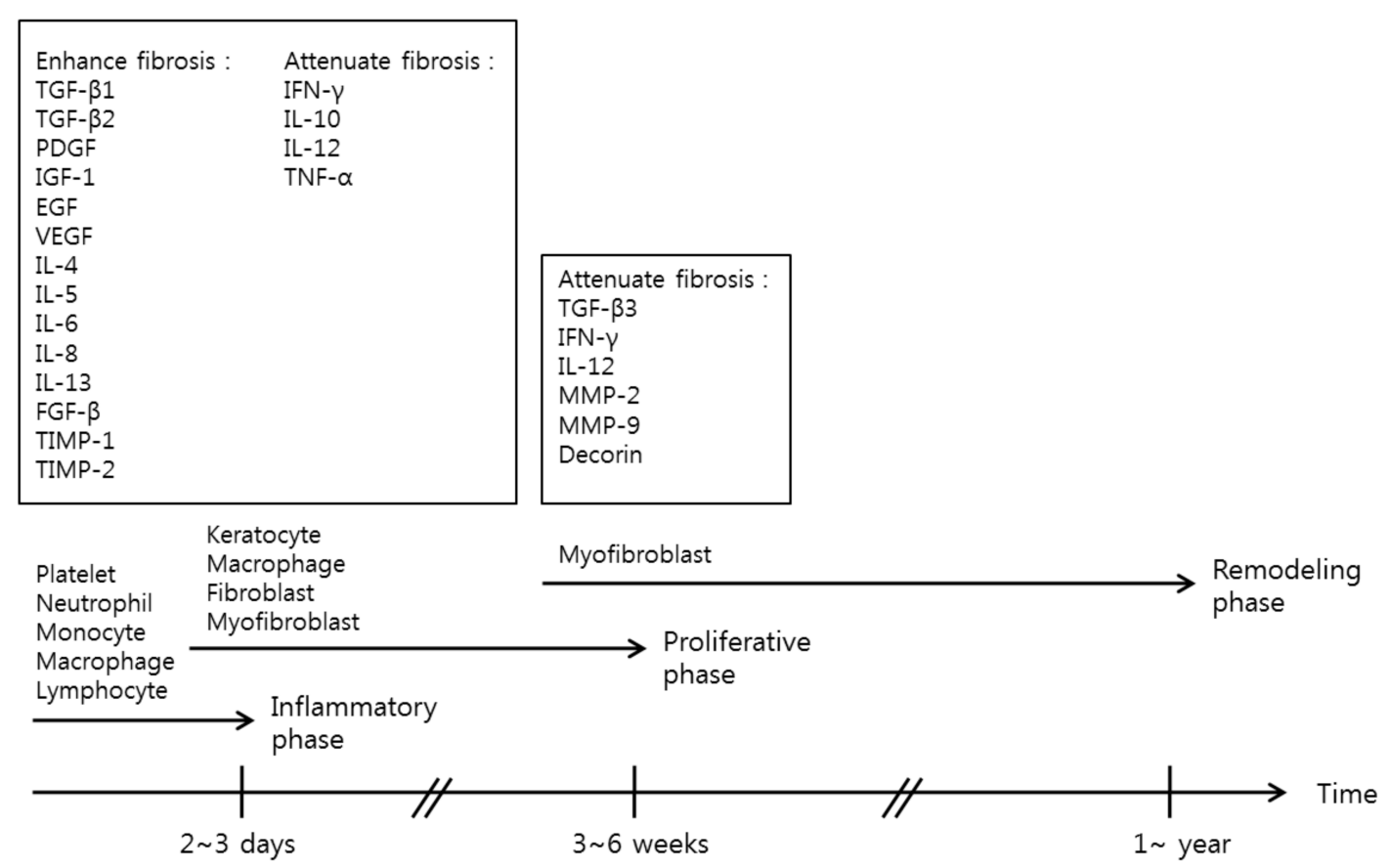

Figure 2. Important proteins and cytokines in the wound healing processes. The classical model of wound healing involves three distinct, but overlapping phases that follow a time sequence: the inflammatory, proliferative and remodeling phases. Important cells, proteins and cytokines in each phase are listed. 


\subsection{Inflammatory and Proliferative Phase}

Prolonged and excessive inflammatory reactions result within the context of increased fibroblast activity, which in turn produces excessive ECM. In this phase, degranulation of platelets releases and activates transforming growth factor $\beta$ (TGF- $\beta$ ), particularly TGF- $\beta 1$, TGF- $\beta 2$, platelet-derived growth factor (PDGF), insulin-like growth factor (IGF-1) and epidermal growth factor (EGF). Vascular endothelial growth factor (VEGF), which is produced by epidermal cells, is a positive regulator of angiogenesis. Because of this, overexpression of VEGF is related to excessive capillary formation, collagen type I production and overall scar volume increase [9]. These cytokines are not only fibrogenic growth factors, but also chemotactic agents for epithelial cells, endothelial cells, neutrophils, macrophages, mast cells and fibroblasts [4,8]. Fibroblasts originating in keloid tissues show increased receptors to these growth factors and demonstrate increased responsiveness compared with fibroblasts from normal tissues [10-13]. Tissue inhibitors of metalloproteinases (TIMPs) are endogenous inhibitors of matrix metalloproteinases (MMPs); thus, increased levels of TIMPs, especially TIMP-1 and TIMP-2, are associated with hypertrophic scar formation [9]. Tumor necrosis factor- $\alpha$ (TNF- $\alpha$ ) is an inflammatory cytokine produced by monocytes and macrophages during the inflammatory phase. It has been known that this cytokine induces collagen degranulation and contributes to minimizing excessive scarring. One suggested mechanism is that TNF- $\alpha$ increases the MMP1/TIMP3, MMP2/TIMP3 ratios [14]. However, other studies showed that the biologic effect of TNF- $\alpha$ was not the same on the fibroblasts from lung and skin tissues showing tissue specificity [15] and TNF- $\alpha$ induced epithelial-mesenchymal transition in human skin wound healing [16]. Therefore, it is still unclear whether TNF- $\alpha$ would promote or attenuate scar formation.

Immune responses are also related to wound healing processes. T helper CD4 cells are thought to be major immunoregulatory cells during wound healing processes. CD4 T cells express Th1 or Th2 responses [17]. Th1 responses produce interferon- $\gamma$ and interleukin (IL)- 12 and are thought to be related to the attenuation of fibrogenesis. Th2 responses of CD4 cells are generally likely related to fibrogenesis. IL-4, IL-5, IL-6 and IL-13 are thought to be related to pro-fibrosis [18,19], but IL-10 is thought to be related to anti-fibrosis [20-22]. These cytokines are essential for promoting or impeding the fibroblast recruitment and proliferation, ECM deposition, angiogenesis and re-epithelialization [4]. Endothelial cytokines including IL-8, IGF-1, fibroblast growth factor (FGF)- $\beta$ and heparin promote angiogenesis. Wound re-epithelialization is enhanced by EGF, TGF- $\alpha$ and IGF-1 [4].

\subsection{Remodeling Phase}

During the remodeling phase, excessive ECM is degraded, and collagen type III, an immature collagen form, is converted to mature collagen type I. TGF- $\beta 3$ is considered to play a role in reducing the newly-synthesized ECM [23]. Significantly lower TGF- $\beta 3$ mRNA expression was found in keloid tissues $[24,25]$. However, TGF- $\beta$ isoforms (TGF- $\beta 1$, TGF- $\beta 2$ and TGF- $\beta 3$ ) do not present its activity as isolated ligands, but are also associated with receptors and activity modulators; therefore, the mere presence or absence of TGF- $\beta$ may not fully explain abnormal wound healing [26]. Members of the MMP family have major effects on ECM degradation and remodeling and mediate the degradation of type III and type I collagens, the major components of ECM [27,28]. MMP-2 and MMP-9 are active during the remodeling phase. MMP-9 is involved in degradation of type IV and V collagens, fibronectin and elastin. MMP-2 plays an important role in ECM remodeling by degrading denatured collagen $[29,30]$. MMPs have a downregulating effect on inflammation by decreasing and antagonizing chemokines [31,32]. Immunity, cell migration and angiogenesis are also influenced by MMPs [33]. MMP activities are regulated by TIMPs. Decorin is a proteoglycan component of dermal connective tissue that binds to type I collagen fibrils and influences TGF- $\beta$ [34]. This protein is decreased in keloids and hypertrophic scars [35]. By binding and neutralizing TGF- $\beta$, decorin decreases the stimulatory effects of TGF- $\beta$ on collagen, fibronectin and glycosaminoglycan synthesis [17]. Decorin also inhibits angiogenesis by interacting with VEGF receptors (VEGFR2) and by inhibiting hepatocyte growth 
factors and PDGF [36]. Decorin's antifibrotic properties are receiving attention as a future therapeutic agent $[37,38]$.

\section{Recent Findings of Scar Biology}

Here, we introduce some recent findings on scar biology. These consist of some factors that influence pro-fibrotic or anti-fibrotic pathways.

\subsection{Hypoxia}

Oxygen has long been known to be an important factor in wound healing $[39,40]$. There have been many reports suggesting that a hypoxic environment is associated with keloid formation [41,42]. Zhao et al. measured the quantity of hypoxia inducible factor (HIF)-1 $\alpha$ in keloid and normal tissues and reported that keloid tissues are relatively hypoxic tissues compared to normoxic tissues, and hypoxia induces a pro-fibrotic state in dermal fibroblasts via the TGF- $\beta 1$ /SMAD3 pathway [43].

\subsection{Periostin}

Periostin is a secreted extracellular matrix (ECM) protein, which was originally identified in osteoblast, periodontal ligament and periosteum [44]. This matricellular protein is expressed in the basement membrane, dermis and hair follicle [45]. Periostin is induced by TGF- $\beta$ in human dermal fibroblast and has an important role in wound healing and scar pathogenesis by inducing angiogenesis, fibroblast proliferation and myofibroblast persistence [45-47]. It starts to increase its expression from a few days after injury, peaking after about seven days after injury and decreasing afterwards [48,49]. Many authors have reported that periostin is abnormally elevated in hypertrophic scars and keloids compared to normal tissues $[45,46,50,51]$ and implicates periostin as a possible therapeutic target in the treatment of hypertrophic scars and keloid.

\subsection{MicroRNAs}

MicroRNAs (miRNAs) are a group of short noncoding RNAs that pair complementarily with target genes and silence that genes post-transcriptionally. It thereby regulates negatively the expression of their target genes. miRNAs are thought to be deregulated in many skin diseases such as malignant skin diseases and keloids [52-55]. Some researchers performed miRNA expression microarrays in keloids and normal tissues $[55,56]$ and reported upregulated or downregulated miRNAs in keloid tissues compared to normal tissues. miRNA-199a-5p [57], miRNA-21 [58-61], miRNA-146a [62], miRNA-1224-5p [56], miRNA-31 [63], and so forth, were investigated and showed potential in the treatment of hypertrophic scars and keloids.

\section{Preventions and Treatment Strategies for Hypertrophic Scars and Keloids}

Because the processes are so complicated, the definitive processes that underlie excessive scar formation are yet to be elucidated. So far, preventions and treatment strategies mainly focus on reducing inflammation. Other therapies, targeting genes and molecules, require more study prior to being introduced in clinical practice. The current treatment strategies for hypertrophic scars and keloids are listed below and summarized in Table 1. 
Table 1. Current treatment strategies for hypertrophic scars and keloids.

\begin{tabular}{|c|c|c|c|}
\hline Categories & Modalities & Suggested Mechanisms & Use \\
\hline \multirow{4}{*}{ Prophylaxis } & Tension-free closure & $\begin{array}{l}\text {-Reduce inflammation by reducing } \\
\text { mechanotransduction }\end{array}$ & $\begin{array}{l}\text {-Debridement of inviable tissues, } \\
\text { adequate hemostasis } \\
\text {-Rapid tension free primary closure }\end{array}$ \\
\hline & Taping or silicone sheeting & $\begin{array}{l}\text {-Reduce inflammation by reducing } \\
\text { mechanotransduction: occlusion } \\
\text { and hydration }\end{array}$ & $\begin{array}{l}\text {-Start } 2 \text { weeks after primary } \\
\text { wound treatment } \\
-12 \mathrm{~h} \text { a day for at least } 2 \text { months }\end{array}$ \\
\hline & Flavonoids & $\begin{array}{l}\text {-Induction of MMPs } \\
\text {-Inhibition of SMADs expression }\end{array}$ & $\begin{array}{l}\text {-Start } 2 \text { weeks after primary } \\
\text { wound treatment } \\
\text {-Generally twice daily for } 4 \text { to } 6 \text { months }\end{array}$ \\
\hline & Pressure therapy & $\begin{array}{l}\text {-Occlusion of blood vessels } \\
\text {-Inducing apoptosis }\end{array}$ & $\begin{array}{l}\text {-Pressure of } 15 \text { to } 40 \mathrm{mmHg} \\
\text {-More than } 23 \mathrm{~h} \text { a day for at least } 6 \text { months }\end{array}$ \\
\hline \multirow{6}{*}{$\begin{array}{l}\text { Treatment } \\
\text { (current) }\end{array}$} & Corticosteroids & $\begin{array}{l}\text {-Reducing inflammation and proliferation } \\
\text {-Vasoconstriction }\end{array}$ & $\begin{array}{l}\text {-Intralesional injection: triamcinolone } \\
10 \text { to } 40 \mathrm{mg} / \mathrm{mL} \\
-1 \text { to } 2 \text { sessions a month ( } 2 \text { to } 3 \text { sessions, } \\
\text { but can be extended) } \\
\text {-Tapes/plasters, ointments are available } \\
\text {-Combination is common }\end{array}$ \\
\hline & Scar revision & -Direct reduction of scar volume & $\begin{array}{l}\text {-At least } 1 \text { year after primary } \\
\text { wound treatment } \\
\text {-Combination is recommended }\end{array}$ \\
\hline & Cryotherapy & -Scar tissue necrosis & $\begin{array}{l}\text {-Deliver liquid nitrogen using spray, } \\
\text { contact or intralesional needle cryoprobe } \\
-10 \text { to } 20 \text { s freeze-thaw cycles } \\
\text {-Combination is common }\end{array}$ \\
\hline & Radiotherapy & $\begin{array}{l}\text {-Anti-angiogenesis } \\
\text {-Anti-inflammation }\end{array}$ & $\begin{array}{l}\text {-Adjuvant after scar revision } \\
\text {-24-48 h after scar revision surgery } \\
\text {-Total of } 40 \text { Gray or less, over several } \\
\text { divided sessions }\end{array}$ \\
\hline & Laser therapy & $\begin{array}{l}\text {-Vaporize blood vessel } \\
\text {-Anti-inflammation }\end{array}$ & $\begin{array}{l}-585-\mathrm{nm} \text { pulsed dye laser: } 6.0-7.5 \mathrm{~J} / \mathrm{cm}^{2} \\
\left(7 \mathrm{~mm} \text { spot) or } 4.5-5.5 \mathrm{~J} / \mathrm{cm}^{2}(10 \mathrm{~mm} \text { spot})\right. \\
-1064-\mathrm{nm} \text { Nd:YAG laser: } 14 \mathrm{~J} / \mathrm{cm}^{2} \\
(5 \mathrm{~mm} \text { spot) } \\
-2 \text { to } 6 \text { sessions, every } 3-4 \text { weeks }\end{array}$ \\
\hline & 5-Fluorouracil & $\begin{array}{l}\text {-Anti-angiogenesis } \\
\text {-Anti-inflammation }\end{array}$ & $\begin{array}{l}\text {-Intralesional injection: } 50 \mathrm{mg} / \mathrm{mL} \\
\text {-Weekly for } 12 \text { weeks } \\
\text {-Combination is common }\end{array}$ \\
\hline \multirow{6}{*}{$\begin{array}{l}\text { Treatment } \\
\text { (Emerging) }\end{array}$} & MSC * therapy & $\begin{array}{l}\text {-Modulation of proinflammatory } \\
\text { cell activity } \\
\text {-Anti-fibrosis } \\
\text {-Promote normal angiogenetic activity }\end{array}$ & $\begin{array}{l}\text {-Systemic injection } \\
\text {-Local injection (at the wound) } \\
\text {-Engineered MSC-seeded tissue scaffold }\end{array}$ \\
\hline & Fat grafting & -Deliver adipose-tissue derived MSCs & $\begin{array}{l}\text {-Fat injection or fat tissue grafting } \\
\text { underneath or into the wound }\end{array}$ \\
\hline & Interferon & $\begin{array}{l}\text {-Downregulating TGF- } \beta 1 \\
\text {-Attenuates collagen synthesis and } \\
\text { fibroblast proliferation }\end{array}$ & $\begin{array}{l}\text {-Intralesional injection: } 1.5 \times 10^{6} \mathrm{IU} \\
\text { twice daily over } 4 \text { days }\end{array}$ \\
\hline & $\begin{array}{l}\text { Human recombinant } \\
\text { TGF- } \beta 3 / \text { TGF- } \beta 1 \text { or } \\
2 \text { neutralizing antibody }\end{array}$ & -Adjust TGF- $\beta 3$ : TGF- $\beta 1$ or 2 ratio & Not available currently \\
\hline & Botulinum toxin type A & $\begin{array}{l}\text {-Reduce muscle tension during } \\
\text { wound healing } \\
\text {-Arrest cell cycle in non-proliferative stage } \\
\text {-Influence TGF- } \beta 1 \text { expression }\end{array}$ & $\begin{array}{l}\text {-Intralesional injection: } 70 \sim 140 \mathrm{U} \text {, } \\
1 \text { or } 3 \text { months interval, } 3 \text { sessions }\end{array}$ \\
\hline & Bleomycin & $\begin{array}{l}\text {-Decreasing collagen synthesis } \\
\text {-Reduce lysyl-oxidase levels } \\
\text {-Induce apoptosis }\end{array}$ & $\begin{array}{l}\text {-Intralesional injection: } 1.5 \mathrm{IU} / \mathrm{mL}, \\
2 \text { to } 6 \text { sessions at monthly interval }\end{array}$ \\
\hline
\end{tabular}

* MSC: mesenchymal stem cell; MMPs: matrix metalloproteinases; TGF: transforming growth factor.

\subsection{Prevention}

\subsubsection{Tension-Free Primary Closure}

Regardless of a patient's tendency to exhibit bad scars (or not), (1) debridement of inviable or severely contaminated tissues, (2) adequate hemostasis to prevent hematoma, seroma or abscess formation and (3) rapid primary closure using tension-free techniques are wound care basics and are very important for minimizing the effects of bad scars. Wound epithelialization that is delayed beyond 10-14 days increases the risk of hypertrophic scars, and quick primary closure to induce rapid 
epithelialization is necessary to achieve good scarring [64]. The importance of tension-free closure techniques cannot be overstated. Wounds that are subject to tension tend to develop into bad scars [65]. The exact molecular mechanisms that govern how our skin responds to physical tension remain uncertain; however, several pathways that convert mechanical forces into biochemical responses have been investigated and reported. This process is called mechanotransduction [66]. Gurtner et al. reported on the fibrotic effects of mechanical tension and described the preventive effect of offloading wound tension on scar formation [67].

\subsubsection{Passive Mechanical Stabilization}

To prevent wound stretching and consequential mechanotransduction, prolonged passive mechanical wound stabilization has been applied [68-71] using paper tapes or silicone sheets. Paper tapes help alleviate scar formation, and silicone sheeting is superior to paper tapes because it avoids repeated epidermal avulsion.

Other mechanisms of silicone sheets include occlusion and hydration of the scar surface. The inherent antifibrotic properties of silicone are not definite [72]. Silicone sheeting is recommended for use from two weeks after primary wound treatment for more than $12 \mathrm{~h}$ a day for at least two months. For body areas where silicone sheets do not easily fit, silicone gel can be applied.

\subsubsection{Flavonoids}

Flavonoids (or bioflavonoids) are naturally-derived substances from various plants and have been used for preventing severe scar formation. Several studies have reported the efficacy of flavonoid scar gels like Contractubex Gel (Merz Pharma, Frankfurt, Germany) or Mederma Skin Care Gel (Merz Pharmaceuticals, Greensboro, NC, USA). The efficacy of these gel products is controversial [73-77], but other flavonoids like quercetin exert antifibrotic actions. These actions may be mediated through induction of MMP-1 or inhibition of SMAD2, SMAD3 or SMAD4 expression [77,78]. The instructions of flavonoids, for instance, Contractubex Gel, is as follows: (1) start two weeks after primary wound treatment; and (2) twice daily for four to six months.

\subsubsection{Pressure Therapy}

Cutaneous wound compression has been used not only for prevention, but also for treatment of hypertrophic scars and keloids. Although pressure therapy reduces the subjective and objective signs and symptoms of hypertrophic scars and keloids, the scientific evidence supporting their use is weak, and their clinical efficacy is also controversial [79]. The suggested mechanisms underlying pressure therapy include occlusion of blood vessels and limiting the delivery of inflammatory cytokines, nutrients and oxygen from blood vessels to scar tissue [80-84]. Increasing apoptosis may be another mechanism of pressure therapy [85]. There are no comparative analyses of pressure amount, and the pressure amount that is used clinically relies on empirical reports. Currently, the recommended amount is $15-40 \mathrm{~mm} \mathrm{Hg}$ for more than $23 \mathrm{~h}$ a day for at least six months [83,86].

\subsection{Current Treatment Strategies}

\subsubsection{Corticosteroids}

Intralesional steroid injection, steroid tapes/plasters and steroid ointments have been used to treat hypertrophic scars and keloids. Intralesional injection is the most popular method for steroid administration, although steroid tapes/plasters are gaining popularity [87]. The mechanism underlying this therapy is attributed to its anti-inflammatory effect [72]. In addition, steroid therapy seems to reduce collagen synthesis, glycosaminoglycan production, fibroblast proliferation and degeneration of collagen and fibroblasts [88,89]. Another suggested mechanism is induction of vasoconstriction mediated by binding of the topical steroid to classical glucocorticoid receptors [2]. Resolution rates for keloids treated with intralesional steroid injections are variable and range from 
$50 \%$ to $100 \%$ and recur in $9 \%$ to $50 \%$ [90]. Most previous studies used triamcinolone acetonide (TAC), injected alone or in combination with other treatment modalities such as 5-FU, verapamil, cryotherapy or surgery. The concentrations of injectable TAC vary from 10 to $40 \mathrm{mg} / \mathrm{mL}$, but the recommended concentration of TAC in monotherapy is $40 \mathrm{mg} / \mathrm{mL}$ for keloid resolution [91]. The injection is performed 1-2 times a months until the scar has flattened. Intralesional steroid injections could cause side effects such as skin atrophy or telangiectasia.

\subsubsection{Scar Revision Surgery}

Surgical excision is a traditional treatment for hypertrophic scars and keloids. The remodeling phase of classical wound healing may last for more than one year; therefore, excision of hypertrophic scars or keloids should be considered after at least one year of primary wound treatment therapy. As time goes by, hypertrophic scars tend to regress naturally or with conservative treatment such as steroid injections. Therefore, in many cases, there is no need to perform scar revision surgery. For keloids, surgical excision alone frequently results in disappointing outcomes. To improve postoperative surgical outcomes, multimodal combination therapy such as postoperative steroid application or radiotherapy might be added. When surgeons perform scar revision surgery, they should establish tension-free wound closure in order to decrease tension-related inflammation and thereby reduce recurrence. Various techniques including three-layered sutures, subcutaneous/fascial tensile reduction sutures, Z-plastics or local flap reconstruction can be utilized on a case-by-case basis [92,93]. Recurrence rates of hypertrophic scars after scar revision surgery are low, but the recurrence rate of keloids after scar revision surgery is $45 \%$ to $100 \%$ [94-96].

\subsubsection{Cryotherapy}

Cryotherapy has been used to treat hypertrophic scars or keloids as a monotherapy or in conjunction with other therapies such as intralesional steroid injections [97]. Treatments that combine cryotherapy and intralesional triamcinolone injections significantly improve hypertrophic scars and keloids [98-100]. Delivery methods for cryotherapy are variable and include sprays, contact or the intralesional-needle cryoprobe method. The intralesional-needle cryoprobe method shows better results than the spray or contact method, producing rapid re-epithelialization [101]. The suggested mechanism underlying cryotherapy is tissue necrosis induced by vascular damage. It seems that necrotized tissues induced by frostbite (as opposed to burn injury) secrete unique inflammatory cytokines; therefore, the responses of fibroblasts may differ [2]. Cryotherapy success rates range from 32 to $74 \%$ after several sessions [102-104].

\subsubsection{Radiotherapy}

Several studies have shown the effectiveness of radiotherapy on keloid treatment. Both external beam therapy and brachytherapy (or internal radiation therapy) have been used and studied for treatment of keloids. Radiotherapy is generally conducted as an adjuvant treatment 24 to $48 \mathrm{~h}$ after scar revision surgery, and the recommend radiation dose is 40 Gray over several divided sessions to minimize adverse effects [105]. The suggested mechanism of radiotherapy for treating keloids is anti-angiogenesis and successive anti-fibroblast activity. Suppression of angiogenesis decreases delivery of inflammatory cytokines, and successive inhibition of fibroblast activity results in decreased collagen synthesis, thus suppressing keloid development [106,107]. Radiotherapy carries an inherent risk of carcinogenesis; therefore, even though the risk is low [108,109], radiation-vulnerable areas, including the thyroid and breast, should be treated after achieving informed consent and with abundant cautions. Shen et al. reported the recurrence rate of 9.59\% [109]. Recently, radioactive skin patches have been used for localized skin diseases like skin cancers or keloids [110,111]. Radioactive skin patches use various kinds of radionuclides and have variable effectiveness for treating keloids. These patches are frequently used in combination with other available treatment. 


\subsubsection{Laser Therapy}

Laser therapy was introduced for keloid treatment in the 1980s [112], and several kinds of lasers with various wavelengths were investigated and reported. Among these, the most popular laser used to treat hypertrophic scars and keloids is the 585-nm pulsed dye laser (PDL) [113]. The recommended energy is 6.0 to $7.5 \mathrm{~J} / \mathrm{cm}^{2}$ (7-mm spot) or 4.5 to $5.5 \mathrm{~J} / \mathrm{cm}^{2}$ (10-mm spot) [114], and two to six sessions of treatment may be needed [113]. The 1064-nm Nd:YAG laser is another popular laser for treating hypertrophic scars and keloids. For this laser, the recommended energy is $14 \mathrm{~J} / \mathrm{cm}^{2}$ (5-mm spot), with the procedure being repeated every three to four weeks $[115,116]$. These laser treatments vaporize blood vessels. By doing this, inflammatory cytokines are limited in their ability to reach hypertrophic scars and keloids, thereby suppressing the development of aberrant scars. Possible side effects of laser therapy include hyperpigmentation, hypopigmentation, blister formation and postoperative purpura [117-120].

\subsubsection{5-Fluorouracil}

5-FU is a medication mainly used to treat cancer. By injecting it into a vein, it can be used for the treatment of esophageal, stomach, pancreatic, colon, breast and cervical cancers. It can also be used topically for actinic keratosis and basal cell carcinoma in a cream or solution formulation [87]. 5-FU has also been used to treat keloids [121]. The suggested mechanism is anti-angiogenesis, anti-fibroblast proliferation and anti-collagen Type I expression induced by TGF- $\beta$ [122-124]. This therapy is used solely or in combination with another treatment, and intralesional injection is the preferred method of delivery. Nanda et al. reported scar size reduction in a majority of patients in whom 5-FU was injected intralesionally weekly for 12 weeks in a concentration of $50 \mathrm{mg} / \mathrm{mL}$ [122]. Possible side effects include pain and ulceration. A systematic review reported $45 \%$ to $96 \%$ of effectiveness [125].

\subsection{Emerging Therapies}

\subsubsection{Mesenchymal Stem Cell Therapy}

Mesenchymal stem cells (MSCs) have immunomodulatory and antifibrotic effects by secreting paracrine growth factors [126-129]. The antifibrotic effects of MSC on fibrotic diseases such as myocardial infarctions, renal fibrosis or liver cirrhosis have been investigated and reported [130-136]. MSCs are also used to prevent or attenuate excessive inflammatory processes that are characteristic of hypertrophic scars and keloids. MSC treatments have variable delivery methods and doses [137]. Delivery is conducted via systemic injections, local injections (at the wound, intradermal or subcutaneously) or via an engineered MSC-seeded tissue scaffold [138-141]. The possible mechanisms underlying MSC treatment include: (1) modulation and inhibition of proinflammatory cell activity; (2) antifibrotic activity via downregulation of myofibroblast differentiation and collagen type I and III production; and (3) promotion of normal angiogenetic activity that aids in normal wound healing $[137,142]$. Even though many researchers have reported anti-inflammatory and anti-fibrotic effects of MSC, there are reports of possible proinflammatory actions of MSC [143-145]. More investigations and long-term preclinical studies should be conducted to apply this method to clinical practice.

\subsubsection{Fat Grafting}

Autologous fat grafting or lipotransfer, underneath or into the wound, has been performed for patients with hypertrophic scars or keloids. Several studies have reported the effectiveness of fat grafting on severely-scarred lesions [146-148]. These reports showed beneficial effects on excessive scar lesions, and side effects were rarely reported. The mechanism underlying fat injections is believed to be that transferred fat tissues deliver adipose-tissue derived MSCs to the wound. 


\subsubsection{Interferon}

Interferon (IFN) is comprised of cytokines that have anti-proliferative and anti-fibrotic effects. As mentioned earlier, IFNs attenuate collagen synthesis and fibroblast proliferation by downregulating TGF- $\beta 1$. Although adverse effects including pain at the injection site and flu-like symptoms are relatively common in IFN treatment, some authors reported a good outcome of combination therapy of IFN $\alpha-2 b$ with TAC injection [149,150].

\subsubsection{Transforming Growth Factor- $\beta$}

TGF- $\beta$ isoforms (TGF- $\beta 1,2,3$ ) had long been a target of anti-keloid therapy. Several studies showed that the ratio of TGF- $\beta 3$ and TFG- $\beta 1$ and 2 is important in scar progression or remission $[151,152]$. Many studies had been performed to investigate the effect of exogenous TGF- $\beta 1$ and 2 neutralizing antibodies and exogenous TFG- $\beta 3$ and had proven the effect of TGF- $\beta$ isoforms; TGF- $\beta 1$ and 2 increase fibrosis, and TGF- $\beta 3$ attenuates fibrosis [153]. Recombinant human TGF- $\beta 3$, avotermin (planned trade name Juvista) showed successful results in phase I/II clinical trials [154-156], but failed in phase III clinical trials.

\subsubsection{Botulinum Toxin A}

Botulinum toxin, which is derived from Clostridium botulinum, is a potent neurotoxin that blocks neuromuscular transmission. Some authors have reported that botulinum toxin type A can minimize scar formation by reducing muscle tension during wound healing, causing the fibroblast cell cycle to be paused in a non-proliferative state, G0 or G1, and influencing TGF- $\beta 1$ expression [157-161]. Intralesional injection was the preferred delivery method, and 70-140 U of Type A botulinum toxin was delivered per sessions at one- or three-month intervals for three or nine months (three sessions) [160,162-164]. Treatment outcomes were generally favorable, and patient satisfaction was high. Improvement was also reported regarding pain, tenderness and itching sensation $[160,162,163]$.

\subsubsection{Bleomycin}

Bleomycin is a cytotoxic, antineoplastic, antiviral and antibacterial agent [165], derived from Streptomyces verticillus, and has been used for dermatologic diseases such as warts. This agent has also been used for hypertrophic scars and keloids. Several studies have found that bleomycin-treated human dermal fibroblasts showed diminished collagen synthesis, even with the co-existence of TFG- $\beta 1$, and a reduction in the levels of lysyl-oxidase, which is involved in the maturation of collagen. In addition, apoptosis was also induced by bleomycin treatment [166-169]. Intralesional injection is the preferred delivery method, and $1.5 \mathrm{IU} / \mathrm{mL}$ of bleomycin were injected two to six sessions at monthly intervals. Several studies reported that complete flattening was achieved in $54 \%$ to $73 \%$ of keloid patients [166,167] and other symptoms like itching and pain were also resolved. Possible side effects include injection site pain, ulceration, atrophy and hyperpigmentation, but systemic side effects were not observed [165,167].

\section{Conclusions}

Hypertrophic scars and keloids result from abnormal wound healing. Excessive ECM deposition is characteristic of these lesions. Increased inflammatory and proliferative processes and decreased remodeling processes cause excessive ECM deposition. Genetic and systemic factors are also related to these excessively scarring lesions. Although encouraging results of molecular- or cytokine-targeting therapies are being continuously reported, current prophylaxis and treatment strategies still mainly focus on decreasing inflammatory processes. Further understanding of the mechanisms underlying excessive scarring is needed to develop more effective prophylaxis and treatment strategies. 
Acknowledgments: No funding was received for this study.

Author Contributions: Ho Jun Lee: conception of the work, acquisition and analysis of data, drafting the work, approved the submitted version, agreed to be personally accountable for the author's own contributions and for ensuring that questions related to the accuracy or integrity of any part of the work; Yong Ju Jang: conception of the work, substantively revised the draft, approved the submitted version, agreed to be personally accountable for the author's own contributions and for ensuring that questions related to the accuracy or integrity of any part of the work.

Conflicts of Interest: The authors declare no conflict of interest.

\section{References}

1. Sund, B. New Development in Wound Care; PJB Publications: London, UK, 2000; pp. 1-255.

2. Ogawa, R. Keloid and Hypertrophic Scars Are the Result of Chronic Inflammation in the Reticular Dermis. Int. J. Mol. Sci. 2017, 18, 606. [CrossRef] [PubMed]

3. Chiang, R.S.; Borovikova, A.A.; King, K.; Banyard, D.A.; Lalezari, S.; Toranto, J.D.; Paydar, K.Z.; Wirth, G.A.; Evans, G.R.; Widgerow, A.D. Current concepts related to hypertrophic scarring in burn injuries. Wound Repair Regen. 2016, 24, 466-477. [CrossRef] [PubMed]

4. Tredget, E.E.; Nedelec, B.; Scott, P.G.; Ghahary, A. Hypertrophic scars, keloids, and contractures. The cellular and molecular basis for therapy. Surg. Clin. N. Am. 1997, 77, 701-730. [CrossRef]

5. Imhof, B.A.; Jemelin, S.; Ballet, R.; Vesin, C.; Schapira, M.; Karaca, M.; Emre, Y. CCN1/CYR61-mediated meticulous patrolling by Ly6Clow monocytes fuels vascular inflammation. Proc. Natl. Acad. Sci. USA 2016, 113, E4847-E4856. [CrossRef] [PubMed]

6. Grose, R.; Werner, S. Wound-healing studies in transgenic and knockout mice. Mol. Biotechnol. 2004, 28, 147-166. [CrossRef]

7. Werner, S.; Krieg, T.; Smola, H. Keratinocyte-fibroblast interactions in wound healing. J. Investig. Dermatol. 2007, 127, 998-1008. [CrossRef] [PubMed]

8. Zhu, Z.; Ding, J.; Tredget, E.E. The molecular basis of hypertrophic scars. Burns Trauma 2016, 4, 2. [CrossRef] [PubMed]

9. Wang, P.; Jiang, L.Z.; Xue, B. Recombinant human endostatin reduces hypertrophic scar formation in rabbit ear model through down-regulation of VEGF and TIMP-1. Afr. Health Sci. 2016, 16, 542-553. [CrossRef] [PubMed]

10. Tuan, T.L.; Nichter, L.S. The molecular basis of keloid and hypertrophic scar formation. Mol. Med. Today 1998, 4, 19-24. [CrossRef]

11. Ishihara, H.; Yoshimoto, H.; Fujioka, M.; Murakami, R.; Hirano, A.; Fujii, T.; Ohtsuru, A.; Namba, H.; Yamashita, S. Keloid fibroblasts resist ceramide-induced apoptosis by overexpression of insulin-like growth factor I receptor. J. Investig. Dermatol. 2000, 115, 1065-1071. [CrossRef] [PubMed]

12. Butler, P.D.; Longaker, M.T.; Yang, G.P. Current progress in keloid research and treatment. J. Am. Coll. Surg. 2008, 206, 731-741. [CrossRef] [PubMed]

13. Ladak, A.; Tredget, E.E. Pathophysiology and management of the burn scar. Clin. Plast. Surg. 2009, 36, 661-674. [CrossRef] [PubMed]

14. Chen, X.; Thibeault, S.L. Role of tumor necrosis factor- $\alpha$ in wound repair in human vocal fold fibroblasts. Laryngoscope 2010, 120, 1819-1825. [CrossRef] [PubMed]

15. Mariani, T.J.; Sandefur, S.; Roby, J.D.; Pierce, R.A. Collagenase-3 induction in rat lung fibroblasts requires the combined effects of tumor necrosis factor- $\alpha$ and 12-lipoxygenase metabolites: A model of macrophage-induced, fibroblast driven extracellular matrix remodeling during inflammatory lung injury. Mol. Biol. Cell 1998, 9, 1411-1424. [CrossRef] [PubMed]

16. Yan, C.; Grimm, W.A.; Garner, W.L.; Qin, L.; Travis, T.; Tan, N.; Han, Y.P. Epithelial to mesenchymal transition in human skin wound healing is induced by tumor necrosis factor- $\alpha$ through bone morphogenic protein-2. Am. J. Pathol. 2010, 176, 2247-2258. [CrossRef] [PubMed]

17. Armour, A.; Scott, P.G.; Tredget, E.E. Cellular and molecular pathology of HTS: Basis for treatment. Wound Repair Regen. 2007, 15 (Suppl. S1), S6-S17. [CrossRef] [PubMed]

18. Doucet, C.; Brouty-Boye, D.; Pottin-Clemenceau, C.; Canonica, G.W.; Jasmin, C.; Azzarone, B. Interleukin (IL) 4 and IL-13 act on human lung fibroblasts. Implication in asthma. J. Clin. Investig. 1998, 101, 2129-2139. [CrossRef] [PubMed] 
19. Wynn, T.A. Fibrotic disease and the Th1/Th2 paradigm. Nat. Rev. Immunol. 2004, 4, 583-594. [CrossRef] [PubMed]

20. Van den Broek, L.J.; van der Veer, W.M.; de Jong, E.H.; Gibbs, S.; Niessen, F.B. Suppressed inflammatory gene expression during human hypertrophic scar compared to normotrophic scar formation. Exp. Dermatol. 2015, 24, 623-629. [CrossRef] [PubMed]

21. Namazi, M.R.; Fallahzadeh, M.K.; Schwartz, R.A. Strategies for prevention of scars: What can we learn from fetal skin? Int. J. Dermatol. 2011, 50, 85-93. [CrossRef] [PubMed]

22. Liechty, K.W.; Kim, H.B.; Adzick, N.S.; Crombleholme, T.M. Fetal wound repair results in scar formation in interleukin-10-deficient mice in a syngeneic murine model of scarless fetal wound repair. J. Pediatr. Surg. 2000, 35, 866-872. [CrossRef] [PubMed]

23. Bock, O.; Yu, H.; Zitron, S.; Bayat, A.; Ferguson, M.W.; Mrowietz, U. Studies of transforming growth factors $\beta 1-3$ and their receptors I and II in fibroblast of keloids and hypertrophic scars. Acta Derm. Venereol. 2005, 85, 216-220. [CrossRef] [PubMed]

24. Lee, T.Y.; Chin, G.S.; Kim, W.J.; Chau, D.; Gittes, G.K.; Longaker, M.T. Expression of transforming growth factor $\beta$ 1, 2, and 3 proteins in keloids. Ann. Plast. Surg. 1999, 43, 179-184. [CrossRef] [PubMed]

25. Xia, W.; Phan, T.T.; Lim, I.J.; Longaker, M.T.; Yang, G.P. Complex epithelial-mesenchymal interactions modulate transforming growth factor- $\beta$ expression in keloid-derived cells. Wound Repair Regen. 2004, 12, 546-556. [CrossRef] [PubMed]

26. Lu, L.; Saulis, A.S.; Liu, W.R.; Roy, N.K.; Chao, J.D.; Ledbetter, S.; Mustoe, T.A. The temporal effects of anti-TGF- $\beta 1$, 2, and 3 monoclonal antibody on wound healing and hypertrophic scar formation. J. Am. Coll. Surg. 2005, 201, 391-397. [CrossRef] [PubMed]

27. Fujiwara, M.; Muragaki, Y.; Ooshima, A. Keloid-derived fibroblasts show increased secretion of factors involved in collagen turnover and depend on matrix metalloproteinase for migration. Br. J. Dermatol. 2005, 153, 295-300. [CrossRef] [PubMed]

28. Ghahary, A.; Ghaffari, A. Role of keratinocyte-fibroblast cross-talk in development of hypertrophic scar. Wound Repair Regen. 2007, 15 (Suppl. S1), S46-S53. [CrossRef] [PubMed]

29. Mauviel, A. Cytokine regulation of metalloproteinase gene expression. J. Cell. Biochem. 1993, 53, $288-295$. [CrossRef] [PubMed]

30. Zhang, Y.; McCluskey, K.; Fujii, K.; Wahl, L.M. Differential regulation of monocyte matrix metalloproteinase and TIMP-1 production by TNF- $\alpha$, granulocyte-macrophage CSF, and IL-1 $\beta$ through prostaglandin-dependent and -independent mechanisms. J. Immunol. 1998, 161, 3071-3076. [PubMed]

31. McQuibban, G.A.; Gong, J.H.; Tam, E.M.; McCulloch, C.A.; Clark-Lewis, I.; Overall, C.M. Inflammation dampened by gelatinase A cleavage of monocyte chemoattractant protein-3. Science 2000, 289, 1202-1206. [CrossRef] [PubMed]

32. McQuibban, G.A.; Gong, J.H.; Wong, J.P.; Wallace, J.L.; Clark-Lewis, I.; Overall, C.M. Matrix metalloproteinase processing of monocyte chemoattractant proteins generates CC chemokine receptor antagonists with anti-inflammatory properties in vivo. Blood 2002, 100, 1160-1167. [PubMed]

33. Rohani, M.G.; Parks, W.C. Matrix remodeling by MMPs during wound repair. Matrix Biol. 2015, 44, $113-121$. [CrossRef] [PubMed]

34. Krumdieck, R.; Hook, M.; Rosenberg, L.C.; Volanakis, J.E. The proteoglycan decorin binds C1q and inhibits the activity of the C1 complex. J. Immunol. 1992, 149, 3695-3701. [PubMed]

35. Scott, P.G.; Dodd, C.M.; Tredget, E.E.; Ghahary, A.; Rahemtulla, F. Chemical characterization and quantification of proteoglycans in human post-burn hypertrophic and mature scars. Clin. Sci. 1996, 90, 417-425. [CrossRef] [PubMed]

36. Jarvelainen, H.; Sainio, A.; Wight, T.N. Pivotal role for decorin in angiogenesis. Matrix Biol. 2015, 43, 15-26. [CrossRef] [PubMed]

37. Zhang, Z.; Garron, T.M.; Li, X.J.; Liu, Y.; Zhang, X.; Li, Y.Y.; Xu, W.S. Recombinant human decorin inhibits TGF- $\beta 1$-induced contraction of collagen lattice by hypertrophic scar fibroblasts. Burns 2009, 35, 527-537. [CrossRef] [PubMed]

38. Mukhopadhyay, A.; Wong, M.Y.; Chan, S.Y.; Do, D.V.; Khoo, A.; Ong, C.T.; Cheong, H.H.; Lim, I.J.; Phan, T.T. Syndecan-2 and decorin: Proteoglycans with a difference-Implications in keloid pathogenesis. J. Trauma 2010, 68, 999-1008. [CrossRef] [PubMed] 
39. Sen, C.K.; Roy, S. Oxygenation state as a driver of myofibroblast differentiation and wound contraction: Hypoxia impairs wound closure. J. Investig. Dermatol. 2010, 130, 2701-2703. [CrossRef] [PubMed]

40. Nauta, T.D.; van Hinsbergh, V.W.; Koolwijk, P. Hypoxic signaling during tissue repair and regenerative medicine. Int. J. Mol. Sci. 2014, 15, 19791-19815. [CrossRef] [PubMed]

41. Ueda, K.; Yasuda, Y.; Furuya, E.; Oba, S. Inadequate blood supply persists in keloids. Scand. J. Plast. Reconstr. Surg. Hand Surg. 2004, 38, 267-271. [CrossRef] [PubMed]

42. Steinbrech, D.S.; Mehrara, B.J.; Chau, D.; Rowe, N.M.; Chin, G.; Lee, T.; Saadeh, P.B.; Gittes, G.K.; Longaker, M.T. Hypoxia upregulates VEGF production in keloid fibroblasts. Ann. Plast. Surg. 1999, 42,514-519. [CrossRef] [PubMed]

43. Zhao, B.; Guan, H.; Liu, J.Q.; Zheng, Z.; Zhou, Q.; Zhang, J.; Su, L.L.; Hu, D.H. Hypoxia drives the transition of human dermal fibroblasts to a myofibroblast-like phenotype via the TGF- $\beta 1 /$ Smad3 pathway. Int. J. Mol. Med. 2017, 39, 153-159. [CrossRef] [PubMed]

44. Horiuchi, K.; Amizuka, N.; Takeshita, S.; Takamatsu, H.; Katsuura, M.; Ozawa, H.; Toyama, Y.; Bonewald, L.F.; Kudo, A. Identification and characterization of a novel protein, periostin, with restricted expression to periosteum and periodontal ligament and increased expression by transforming growth factor $\beta$. J. Bone Miner. Res. 1999, 14, 1239-1249. [CrossRef] [PubMed]

45. Zhou, H.M.; Wang, J.; Elliott, C.; Wen, W.; Hamilton, D.W.; Conway, S.J. Spatiotemporal expression of periostin during skin development and incisional wound healing: Lessons for human fibrotic scar formation. J. Cell Commun. Signal. 2010, 4, 99-107. [CrossRef] [PubMed]

46. Crawford, J.; Nygard, K.; Gan, B.S.; O'Gorman, D.B. Periostin induces fibroblast proliferation and myofibroblast persistence in hypertrophic scarring. Exp. Dermatol. 2015, 24, 120-126. [CrossRef] [PubMed]

47. Elliott, C.G.; Wang, J.; Guo, X.; Xu, S.W.; Eastwood, M.; Guan, J.; Leask, A.; Conway, S.J.; Hamilton, D.W. Periostin modulates myofibroblast differentiation during full-thickness cutaneous wound repair. J. Cell Sci. 2012, 125, 121-132. [CrossRef] [PubMed]

48. Conway, S.J.; Izuhara, K.; Kudo, Y.; Litvin, J.; Markwald, R.; Ouyang, G.; Arron, J.R.; Holweg, C.T.; Kudo, A. The role of periostin in tissue remodeling across health and disease. Cell. Mol. Life Sci. 2014, 71, 1279-1288. [CrossRef] [PubMed]

49. Jackson-Boeters, L.; Wen, W.; Hamilton, D.W. Periostin localizes to cells in normal skin, but is associated with the extracellular matrix during wound repair. J. Cell Commun. Signal. 2009, 3, 125-133. [CrossRef] [PubMed]

50. Zhang, Z.; Nie, F.; Kang, C.; Chen, B.; Qin, Z.; Ma, J.; Ma, Y.; Zhao, X. Increased periostin expression affects the proliferation, collagen synthesis, migration and invasion of keloid fibroblasts under hypoxic conditions. Int. J. Mol. Med. 2014, 34, 253-261. [CrossRef] [PubMed]

51. Zhang, Z.; Nie, F.; Chen, X.; Qin, Z.; Kang, C.; Chen, B.; Ma, J.; Pan, B.; Ma, Y. Upregulated periostin promotes angiogenesis in keloids through activation of the ERK $1 / 2$ and focal adhesion kinase pathways, as well as the upregulated expression of VEGF and angiopoietin1. Mol. Med. Rep. 2015, 11, 857-864. [CrossRef] [PubMed]

52. Kashiyama, K.; Mitsutake, N.; Matsuse, M.; Ogi, T.; Saenko, V.A.; Ujifuku, K.; Utani, A.; Hirano, A.; Yamashita, S. miR-196a downregulation increases the expression of type I and III collagens in keloid fibroblasts. J. Investig. Dermatol. 2012, 132, 1597-1604. [CrossRef] [PubMed]

53. Liu, Y.; Yang, D.; Xiao, Z.; Zhang, M. miRNA expression profiles in keloid tissue and corresponding normal skin tissue. Aesthet. Plast. Surg. 2012, 36, 193-201. [CrossRef] [PubMed]

54. Lovendorf, M.B.; Skov, L. miRNAs in inflammatory skin diseases and their clinical implications. Expert Rev. Clin. Immunol. 2015, 11, 467-477. [CrossRef] [PubMed]

55. Luan, Y.; Liu, Y.; Liu, C.; Lin, Q.; He, F.; Dong, X.; Xiao, Z. Serum miRNAs Signature Plays an Important Role in Keloid Disease. Curr. Mol. Med. 2016, 16, 504-514. [CrossRef] [PubMed]

56. Yao, X.; Cui, X.; Wu, X.; Xu, P.; Zhu, W.; Chen, X.; Zhao, T. Tumor suppressive role of miR-1224-5p in keloid proliferation, apoptosis and invasion via the TGF- $\beta 1 / \mathrm{Smad} 3$ signaling pathway. Biochem. Biophys. Res. Commun. 2017, 495, 713-720. [CrossRef] [PubMed]

57. Wu, Z.Y.; Lu, L.; Liang, J.; Guo, X.R.; Zhang, P.H.; Luo, S.J. Keloid microRNA expression analysis and the influence of miR-199a-5p on the proliferation of keloid fibroblasts. Genet. Mol. Res. 2014, 13, 2727-2738. [CrossRef] [PubMed] 
58. Liu, Y.; Wang, X.; Yang, D.; Xiao, Z.; Chen, X. MicroRNA-21 affects proliferation and apoptosis by regulating expression of PTEN in human keloid fibroblasts. Plast. Reconstr. Surg. 2014, 134, 561e-573e. [CrossRef] [PubMed]

59. Li, Y.; Zhang, J.; Lei, Y.; Lyu, L.; Zuo, R.; Chen, T. MicroRNA-21 in Skin Fibrosis: Potential for Diagnosis and Treatment. Mol. Diagn. Ther. 2017, 21, 633-642. [CrossRef] [PubMed]

60. Zhou, R.; Wang, C.; Wen, C.; Wang, D. miR-21 promotes collagen production in keloid via Smad7. Burns 2017, 43, 555-561. [CrossRef] [PubMed]

61. Liu, Y.; Li, Y.; Li, N.; Teng, W.; Wang, M.; Zhang, Y.; Xiao, Z. TGF- $\beta 1$ promotes scar fibroblasts proliferation and transdifferentiation via up-regulating microRNA-21. Sci. Rep. 2016, 6, 32231. [CrossRef] [PubMed]

62. Liu, Z.; Lu, C.L.; Cui, L.P.; Hu, Y.L.; Yu, Q.; Jiang, Y.; Ma, T.; Jiao, D.K.; Wang, D.; Jia, C.Y. MicroRNA-146a modulates TGF- $\beta 1$-induced phenotypic differentiation in human dermal fibroblasts by targeting SMAD4. Arch. Dermatol. Res. 2012, 304, 195-202. [CrossRef] [PubMed]

63. Zhang, J.; Xu, D.; Li, N.; Li, Y.; He, Y.; Hu, X.; Lyu, L.; He, L. Downregulation of microRNA-31 inhibits proliferation and induces apoptosis by targeting HIF1AN in human keloid. Oncotarget 2017, 8, 74623-74634. [CrossRef] [PubMed]

64. Bond, J.S.; Duncan, J.A.; Mason, T.; Sattar, A.; Boanas, A.; O’Kane, S.; Ferguson, M.W. Scar redness in humans: How long does it persist after incisional and excisional wounding? Plast. Reconstr. Surg. 2008, 121, 487-496. [CrossRef] [PubMed]

65. Mutalik, S. Treatment of keloids and hypertrophic scars. Indian J. Dermatol. Venereol. Leprol. 2005, 71, 3-8. [CrossRef] [PubMed]

66. Wong, V.W.; Akaishi, S.; Longaker, M.T.; Gurtner, G.C. Pushing back: Wound mechanotransduction in repair and regeneration. J. Investig. Dermatol. 2011, 131, 2186-2196. [CrossRef] [PubMed]

67. Gurtner, G.C.; Dauskardt, R.H.; Wong, V.W.; Bhatt, K.A.; Wu, K.; Vial, I.N.; Padois, K.; Korman, J.M.; Longaker, M.T. Improving cutaneous scar formation by controlling the mechanical environment: Large animal and phase I studies. Ann. Surg. 2011, 254, 217-225. [CrossRef] [PubMed]

68. Atkinson, J.A.; McKenna, K.T.; Barnett, A.G.; McGrath, D.J.; Rudd, M. A randomized, controlled trial to determine the efficacy of paper tape in preventing hypertrophic scar formation in surgical incisions that traverse Langer's skin tension lines. Plast. Reconstr. Surg. 2005, 116, 1648-1656. [CrossRef] [PubMed]

69. Daya, M.; Nair, V. Traction-assisted dermatogenesis by serial intermittent skin tape application. Plast. Reconstr. Surg. 2008, 122, 1047-1054. [CrossRef] [PubMed]

70. Fulton, J.E., Jr. Silicone gel sheeting for the prevention and management of evolving hypertrophic and keloid scars. Dermatol. Surg. 1995, 21, 947-951. [CrossRef] [PubMed]

71. Sawada, Y.; Sone, K. Hydration and occlusion treatment for hypertrophic scars and keloids. Br. J. Plast. Surg. 1992, 45, 599-603. [CrossRef]

72. Reish, R.G.; Eriksson, E. Scar treatments: Preclinical and clinical studies. J. Am. Coll. Surg. 2008, 206, 719-730. [CrossRef] [PubMed]

73. Beuth, J.; Hunzelmann, N.; van Leendert, R.; Basten, R.; Noehle, M.; Schneider, B. Safety and efficacy of local administration of contractubex to hypertrophic scars in comparison to corticosteroid treatment. Results of a multicenter, comparative epidemiological cohort study in Germany. In Vivo 2006, 20, 277-283. [PubMed]

74. Chung, V.Q.; Kelley, L.; Marra, D.; Jiang, S.B. Onion extract gel versus petrolatum emollient on new surgical scars: Prospective double-blinded study. Dermatol. Surg. 2006, 32, 193-197. [CrossRef] [PubMed]

75. Ho, W.S.; Ying, S.Y.; Chan, P.C.; Chan, H.H. Use of onion extract, heparin, allantoin gel in prevention of scarring in chinese patients having laser removal of tattoos: A prospective randomized controlled trial. Dermatol. Surg. 2006, 32, 891-896. [CrossRef] [PubMed]

76. Jackson, B.A.; Shelton, A.J. Pilot study evaluating topical onion extract as treatment for postsurgical scars. Dermatol. Surg. 1999, 25, 267-269. [CrossRef] [PubMed]

77. Phan, T.T.; Lim, I.J.; Sun, L.; Chan, S.Y.; Bay, B.H.; Tan, E.K.; Lee, S.T. Quercetin inhibits fibronectin production by keloid-derived fibroblasts. Implication for the treatment of excessive scars. J. Dermatol. Sci. 2003, 33, 192-194. [CrossRef] [PubMed]

78. Cho, J.W.; Cho, S.Y.; Lee, S.R.; Lee, K.S. Onion extract and quercetin induce matrix metalloproteinase-1 in vitro and in vivo. Int. J. Mol. Med. 2010, 25, 347-352. [PubMed]

79. Atiyeh, B.S. Nonsurgical management of hypertrophic scars: Evidence-based therapies, standard practices, and emerging methods. Aesthet. Plast. Surg. 2007, 31, 468-492. [CrossRef] [PubMed] 
80. Baur, P.S.; Larson, D.L.; Stacey, T.R.; Barratt, G.F.; Dobrkovsky, M. Ultrastructural analysis of pressure-treated human hypertrophic scars. J. Trauma 1976, 16, 958-967. [CrossRef] [PubMed]

81. Kelly, A.P. Medical and surgical therapies for keloids. Dermatol. Ther. 2004, 17, 212-218. [CrossRef] [PubMed]

82. Macintyre, L.; Baird, M. Pressure garments for use in the treatment of hypertrophic scars-An evaluation of current construction techniques in NHS hospitals. Burns 2005, 31, 11-14. [CrossRef] [PubMed]

83. Macintyre, L.; Baird, M. Pressure garments for use in the treatment of hypertrophic scars-A review of the problems associated with their use. Burns 2006, 32, 10-15. [CrossRef] [PubMed]

84. Macintyre, L.; Ferguson, R. Pressure garment design tool to monitor exerted pressures. Burns 2013, 39, 1073-1082. [CrossRef] [PubMed]

85. Reno, F.; Sabbatini, M.; Lombardi, F.; Stella, M.; Pezzuto, C.; Magliacani, G.; Cannas, M. In vitro mechanical compression induces apoptosis and regulates cytokines release in hypertrophic scars. Wound Repair Regen. 2003, 11, 331-336. [CrossRef] [PubMed]

86. Van den Kerckhove, E.; Stappaerts, K.; Fieuws, S.; Laperre, J.; Massage, P.; Flour, M.; Boeckx, W. The assessment of erythema and thickness on burn related scars during pressure garment therapy as a preventive measure for hypertrophic scarring. Burns 2005, 31, 696-702. [CrossRef] [PubMed]

87. Rauscher, G.E.; Kolmer, W.L. Treatment of recurrent earlobe keloids. Cutis 1986, 37, 67-68. [PubMed]

88. Boyadjiev, C.; Popchristova, E.; Mazgalova, J. Histomorphologic changes in keloids treated with Kenacort. J. Trauma 1995, 38, 299-302. [CrossRef] [PubMed]

89. Cruz, N.I.; Korchin, L. Inhibition of human keloid fibroblast growth by isotretinoin and triamcinolone acetonide in vitro. Ann. Plast. Surg. 1994, 33, 401-405. [CrossRef] [PubMed]

90. Robles, D.T.; Berg, D. Abnormal wound healing: Keloids. Clin. Dermatol. 2007, 25, 26-32. [CrossRef] [PubMed]

91. Wong, T.S.; Li, J.Z.; Chen, S.; Chan, J.Y.; Gao, W. The Efficacy of Triamcinolone Acetonide in Keloid Treatment: A Systematic Review and Meta-analysis. Front. Med. 2016, 3, 71. [CrossRef] [PubMed]

92. Ogawa, R.; Akaishi, S.; Huang, C.; Dohi, T.; Aoki, M.; Omori, Y.; Koike, S.; Kobe, K.; Akimoto, M.; Hyakusoku, H. Clinical applications of basic research that shows reducing skin tension could prevent and treat abnormal scarring: The importance of fascial/subcutaneous tensile reduction sutures and flap surgery for keloid and hypertrophic scar reconstruction. J. Nippon Med. Sch. 2011, 78, 68-76. [CrossRef] [PubMed]

93. Ogawa, R.; Akaishi, S.; Kuribayashi, S.; Miyashita, T. Keloids and Hypertrophic Scars Can Now Be Cured Completely: Recent Progress in Our Understanding of the Pathogenesis of Keloids and Hypertrophic Scars and the Most Promising Current Therapeutic Strategy. J. Nippon Med. Sch. 2016, 83, 46-53. [CrossRef] [PubMed]

94. Leventhal, D.; Furr, M.; Reiter, D. Treatment of keloids and hypertrophic scars: A meta-analysis and review of the literature. Arch. Facial Plast. Surg. 2006, 8, 362-368. [CrossRef] [PubMed]

95. Muir, I.F. On the nature of keloid and hypertrophic scars. Br. J. Plast. Surg. 1990, 43, 61-69. [CrossRef]

96. Mustoe, T.A.; Cooter, R.D.; Gold, M.H.; Hobbs, F.D.; Ramelet, A.A.; Shakespeare, P.G.; Stella, M.; Teot, L.; Wood, F.M.; Ziegler, U.E.; et al. International clinical recommendations on scar management. Plast. Reconstr. Surg. 2002, 110, 560-571. [CrossRef] [PubMed]

97. Har-Shai, Y.; Zouboulis, C.C. Intralesional Cryotherapy for the Treatment of Keloid Scars: A Prospective Study. Plast. Reconstr. Surg. 2015, 136, 397e-398e. [CrossRef] [PubMed]

98. Boutli-Kasapidou, F.; Tsakiri, A.; Anagnostou, E.; Mourellou, O. Hypertrophic and keloidal scars: An approach to polytherapy. Int. J. Dermatol. 2005, 44, 324-327. [CrossRef] [PubMed]

99. Jaros, E.; Priborsky, J.; Klein, L. Treatment of keloids and hypertrophic scars with cryotherapy. Acta Med. 1999, 42, 61-63.

100. Yosipovitch, G.; Widijanti Sugeng, M.; Goon, A.; Chan, Y.H.; Goh, C.L. A comparison of the combined effect of cryotherapy and corticosteroid injections versus corticosteroids and cryotherapy alone on keloids: A controlled study. J. Dermatol. Treat. 2001, 12, 87-90. [CrossRef] [PubMed]

101. Har-Shai, Y.; Amar, M.; Sabo, E. Intralesional cryotherapy for enhancing the involution of hypertrophic scars and keloids. Plast. Reconstr. Surg. 2003, 111, 1841-1852. [CrossRef] [PubMed]

102. Rusciani, L.; Paradisi, A.; Alfano, C.; Chiummariello, S.; Rusciani, A. Cryotherapy in the treatment of keloids. J. Drugs Dermatol. 2006, 5, 591-595. [CrossRef] [PubMed] 
103. Rusciani, L.; Rossi, G.; Bono, R. Use of cryotherapy in the treatment of keloids. J. Dermatol. Surg. Oncol. 1993, 19, 529-534. [CrossRef] [PubMed]

104. Zouboulis, C.C.; Blume, U.; Buttner, P.; Orfanos, C.E. Outcomes of cryosurgery in keloids and hypertrophic scars. A prospective consecutive trial of case series. Arch. Dermatol. 1993, 129, 1146-1151. [CrossRef] [PubMed]

105. Ogawa, R.; Mitsuhashi, K.; Hyakusoku, H.; Miyashita, T. Postoperative electron-beam irradiation therapy for keloids and hypertrophic scars: Retrospective study of 147 cases followed for more than 18 months. Plast. Reconstr. Surg. 2003, 111, 547-553. [CrossRef] [PubMed]

106. Ji, J.; Tian, Y.; Zhu, Y.Q.; Zhang, L.Y.; Ji, S.J.; Huan, J.; Zhou, X.Z.; Cao, J.P. Ionizing irradiation inhibits keloid fibroblast cell proliferation and induces premature cellular senescence. J. Dermatol. 2015, 42, 56-63. [CrossRef] [PubMed]

107. Keeling, B.H.; Whitsitt, J.; Liu, A.; Dunnick, C.A. Keloid removal by shave excision with adjuvant external beam radiation therapy. Dermatol. Surg. 2015, 41, 989-992. [CrossRef] [PubMed]

108. McKeown, S.R.; Hatfield, P.; Prestwich, R.J.; Shaffer, R.E.; Taylor, R.E. Radiotherapy for benign disease; assessing the risk of radiation-induced cancer following exposure to intermediate dose radiation. Br. J. Radiol. 2015, 88, 20150405. [CrossRef] [PubMed]

109. Shen, J.; Lian, X.; Sun, Y.; Wang, X.; Hu, K.; Hou, X.; Sun, S.; Yan, J.; Yu, L.; Sun, X.; et al. Hypofractionated electron-beam radiation therapy for keloids: Retrospective study of 568 cases with 834 lesions. J. Radiat. Res. 2015, 56, 811-817. [CrossRef] [PubMed]

110. Vivante, H.; Salgueiro, M.J.; Ughetti, R.; Nicolini, J.; Zubillaga, M. 32P-patch contact brachyradiotherapy in the management of recalcitrant keloids and hypertrophic scars. Indian J. Dermatol. Venereol. Leprol. 2007, 73, 336-339. [PubMed]

111. Bhusari, P.; Shukla, J.; Kumar, M.; Vatsa, R.; Chhabra, A.; Palarwar, K.; Rathore, Y.; De, D.; Kumaran, S.; Handa, S.; et al. Noninvasive treatment of keloid using customized Re-188 skin patch. Dermatol. Ther. 2017, 30. [CrossRef] [PubMed]

112. Apfelberg, D.B.; Maser, M.R.; Lash, H.; White, D.; Weston, J. Preliminary results of argon and carbon dioxide laser treatment of keloid scars. Lasers Surg. Med. 1984, 4, 283-290. [CrossRef] [PubMed]

113. Alster, T.S.; Handrick, C. Laser treatment of hypertrophic scars, keloids, and striae. Semin. Cutan. Med. Surg. 2000, 19, 287-292. [CrossRef] [PubMed]

114. Tanzi, E.L.; Alster, T.S. Laser treatment of scars. Skin Ther. Lett. 2004, 9, 4-7.

115. Koike, S.; Akaishi, S.; Nagashima, Y.; Dohi, T.; Hyakusoku, H.; Ogawa, R. Nd:YAG Laser Treatment for Keloids and Hypertrophic Scars: An Analysis of 102 Cases. Plast. Reconstr. Surg. Glob. Open 2014, 2, e272. [CrossRef] [PubMed]

116. Akaishi, S.; Koike, S.; Dohi, T.; Kobe, K.; Hyakusoku, H.; Ogawa, R. Nd:YAG Laser Treatment of Keloids and Hypertrophic Scars. Eplasty 2012, 12, e1. [PubMed]

117. Alster, T. Laser scar revision: Comparison study of 585-nm pulsed dye laser with and without intralesional corticosteroids. Dermatol. Surg. 2003, 29, 25-29. [CrossRef] [PubMed]

118. Chan, H.H.; Wong, D.S.; Ho, W.S.; Lam, L.K.; Wei, W. The use of pulsed dye laser for the prevention and treatment of hypertrophic scars in chinese persons. Dermatol. Surg. 2004, 30, 987-994. [PubMed]

119. Fiskerstrand, E.J.; Svaasand, L.O.; Volden, G. Pigmentary changes after pulsed dye laser treatment in 125 northern European patients with port wine stains. Br. J. Dermatol. 1998, 138, 477-479. [CrossRef] [PubMed]

120. Hermanns, J.F.; Petit, L.; Hermanns-Le, T.; Pierard, G.E. Analytic quantification of phototype-related regional skin complexion. Skin Res. Technol. 2001, 7, 168-171. [CrossRef] [PubMed]

121. Fitzpatrick, R.E. Treatment of inflamed hypertrophic scars using intralesional 5-FU. Dermatol. Surg. 1999, 25, 224-232. [CrossRef] [PubMed]

122. Nanda, S.; Reddy, B.S. Intralesional 5-fluorouracil as a treatment modality of keloids. Dermatol. Surg. 2004, 30, 54-56. [PubMed]

123. Khan, M.A.; Bashir, M.M.; Khan, F.A. Intralesional triamcinolone alone and in combination with 5-fluorouracil for the treatment of Keloid and Hypertrophic scars. J. Pak. Med. Assoc. 2014, 64, 1003-1007. [PubMed] 
124. Darougheh, A.; Asilian, A.; Shariati, F. Intralesional triamcinolone alone or in combination with 5-fluorouracil for the treatment of keloid and hypertrophic scars. Clin. Exp. Dermatol. 2009, 34, 219-223. [CrossRef] [PubMed]

125. Bijlard, E.; Steltenpool, S.; Niessen, F.B. Intralesional 5-fluorouracil in keloid treatment: A systematic review. Acta Derm. Venereol. 2015, 95, 778-782. [CrossRef] [PubMed]

126. Le Blanc, K. Immunomodulatory effects of fetal and adult mesenchymal stem cells. Cytotherapy 2003, 5, 485-489. [CrossRef] [PubMed]

127. Le Blanc, K.; Mougiakakos, D. Multipotent mesenchymal stromal cells and the innate immune system. Nat. Rev. Immunol. 2012, 12, 383-396. [CrossRef] [PubMed]

128. Ortiz, L.A.; Gambelli, F.; McBride, C.; Gaupp, D.; Baddoo, M.; Kaminski, N.; Phinney, D.G. Mesenchymal stem cell engraftment in lung is enhanced in response to bleomycin exposure and ameliorates its fibrotic effects. Proc. Natl. Acad. Sci. USA 2003, 100, 8407-8411. [CrossRef] [PubMed]

129. Zhang, J.; Guan, J.; Niu, X.; Hu, G.; Guo, S.; Li, Q.; Xie, Z.; Zhang, C.; Wang, Y. Exosomes released from human induced pluripotent stem cells-derived MSCs facilitate cutaneous wound healing by promoting collagen synthesis and angiogenesis. J. Transl. Med. 2015, 13, 49. [CrossRef] [PubMed]

130. Lee, R.H.; Pulin, A.A.; Seo, M.J.; Kota, D.J.; Ylostalo, J.; Larson, B.L.; Semprun-Prieto, L.; Delafontaine, P.; Prockop, D.J. Intravenous hMSCs improve myocardial infarction in mice because cells embolized in lung are activated to secrete the anti-inflammatory protein TSG-6. Cell Stem Cell 2009, 5, 54-63. [CrossRef] [PubMed]

131. Lin, J.S.; Zhou, L.; Sagayaraj, A.; Jumat, N.H.; Choolani, M.; Chan, J.K.; Biswas, A.; Wong, P.C.; Lim, S.G.; Dan, Y.Y. Hepatic differentiation of human amniotic epithelial cells and in vivo therapeutic effect on animal model of cirrhosis. J. Gastroenterol. Hepatol. 2015, 30, 1673-1682. [CrossRef] [PubMed]

132. Prockop, D.J. Concise review: Two negative feedback loops place mesenchymal stem/stromal cells at the center of early regulators of inflammation. Stem Cells 2013, 31, 2042-2046. [CrossRef] [PubMed]

133. Prockop, D.J. Inflammation, fibrosis, and modulation of the process by mesenchymal stem/stromal cells. Matrix Boil. 2016, 51, 7-13. [CrossRef] [PubMed]

134. Prockop, D.J.; Oh, J.Y. Mesenchymal stem/stromal cells (MSCs): Role as guardians of inflammation. Mol. Ther. 2012, 20, 14-20. [CrossRef] [PubMed]

135. Reinders, M.E.; de Fijter, J.W.; Rabelink, T.J. Mesenchymal stromal cells to prevent fibrosis in kidney transplantation. Curr. Opin. Organ Transplant. 2014, 19, 54-59. [CrossRef] [PubMed]

136. Shafiq, M.; Lee, S.H.; Jung, Y.; Kim, S.H. Strategies for recruitment of stem cells to treat myocardial infarction. Curr. Pharm. Des. 2015, 21, 1584-1597. [CrossRef] [PubMed]

137. Seo, B.F.; Jung, S.N. The Immunomodulatory Effects of Mesenchymal Stem Cells in Prevention or Treatment of Excessive Scars. Stem Cells Int. 2016, 2016, 6937976. [CrossRef] [PubMed]

138. Altman, A.M.; Matthias, N.; Yan, Y.; Song, Y.H.; Bai, X.; Chiu, E.S.; Slakey, D.P.; Alt, E.U. Dermal matrix as a carrier for in vivo delivery of human adipose-derived stem cells. Biomaterials 2008, 29, 1431-1442. [CrossRef] [PubMed]

139. Huang, S.P.; Hsu, C.C.; Chang, S.C.; Wang, C.H.; Deng, S.C.; Dai, N.T.; Chen, T.M.; Chan, J.Y.; Chen, S.G.; Huang, S.M. Adipose-derived stem cells seeded on acellular dermal matrix grafts enhance wound healing in a murine model of a full-thickness defect. Ann. Plast. Surg. 2012, 69, 656-662. [CrossRef] [PubMed]

140. Lam, M.T.; Nauta, A.; Meyer, N.P.; Wu, J.C.; Longaker, M.T. Effective delivery of stem cells using an extracellular matrix patch results in increased cell survival and proliferation and reduced scarring in skin wound healing. Tissue Eng. A 2013, 19, 738-747. [CrossRef] [PubMed]

141. Zonari, A.; Martins, T.M.; Paula, A.C.; Boeloni, J.N.; Novikoff, S.; Marques, A.P.; Correlo, V.M.; Reis, R.L.; Goes, A.M. Polyhydroxybutyrate-co-hydroxyvalerate structures loaded with adipose stem cells promote skin healing with reduced scarring. Acta Biomater. 2015, 17, 170-181. [CrossRef] [PubMed]

142. Kaigler, D.; Krebsbach, P.H.; Polverini, P.J.; Mooney, D.J. Role of vascular endothelial growth factor in bone marrow stromal cell modulation of endothelial cells. Tissue Eng. 2003, 9, 95-103. [CrossRef] [PubMed]

143. Liotta, F.; Angeli, R.; Cosmi, L.; Fili, L.; Manuelli, C.; Frosali, F.; Mazzinghi, B.; Maggi, L.; Pasini, A.; Lisi, V.; et al. Toll-like receptors 3 and 4 are expressed by human bone marrow-derived mesenchymal stem cells and can inhibit their T-cell modulatory activity by impairing Notch signaling. Stem Cells 2008, 26, 279-289. [CrossRef] [PubMed] 
144. Waterman, R.S.; Tomchuck, S.L.; Henkle, S.L.; Bncourt, A.M. A new mesenchymal stem cell (MSC) paradigm: Polarization into a pro-inflammatory MSC1 or an Immunosuppressive MSC2 phenotype. PLoS ONE 2010, 5, e10088. [CrossRef] [PubMed]

145. Yan, H.; Wu, M.; Yuan, Y.; Wang, Z.Z.; Jiang, H.; Chen, T. Priming of Toll-like receptor 4 pathway in mesenchymal stem cells increases expression of B cell activating factor. Biochem. Biophys. Res. Commun. 2014, 448, 212-217. [CrossRef] [PubMed]

146. Bruno, A.; Delli Santi, G.; Fasciani, L.; Cempanari, M.; Palombo, M.; Palombo, P. Burn scar lipofilling: Immunohistochemical and clinical outcomes. J. Craniofac. Surg. 2013, 24, 1806-1814. [CrossRef] [PubMed]

147. Negenborn, V.L.; Groen, J.W.; Smit, J.M.; Niessen, F.B.; Mullender, M.G. The Use of Autologous Fat Grafting for Treatment of Scar Tissue and Scar-Related Conditions: A Systematic Review. Plast. Reconstr. Surg. 2016, 137, 31e-43e. [CrossRef] [PubMed]

148. Piccolo, N.S.; Piccolo, M.S.; Piccolo, M.T. Fat grafting for treatment of burns, burn scars, and other difficult wounds. Clin. Plast. Surg. 2015, 42, 263-283. [CrossRef] [PubMed]

149. Al-Khawajah, M.M. Failure of interferon- $\alpha 2 b$ in the treatment of mature keloids. Int. J. Dermatol. 1996, 35 , 515-517. [CrossRef] [PubMed]

150. Lee, J.H.; Kim, S.E.; Lee, A.Y. Effects of interferon- $\alpha 2 b$ on keloid treatment with triamcinolone acetonide intralesional injection. Int. J. Dermatol. 2008, 47, 183-186. [CrossRef] [PubMed]

151. Schrementi, M.E.; Ferreira, A.M.; Zender, C.; DiPietro, L.A. Site-specific production of TGF- $\beta$ in oral mucosal and cutaneous wounds. Wound Repair Regen. 2008, 16, 80-86. [CrossRef] [PubMed]

152. O'Kane, S.; Ferguson, M.W. Transforming growth factor $\beta$ s and wound healing. Int. J. Biochem. Cell Biol. 1997, 29, 63-78. [CrossRef]

153. Shah, M.; Foreman, D.M.; Ferguson, M.W. Neutralisation of TGF- $\beta 1$ and TGF- $\beta 2$ or exogenous addition of TGF- $\beta 3$ to cutaneous rat wounds reduces scarring. J. Cell Sci. 1995, 108 Pt 3, 985-1002. [PubMed]

154. So, K.; McGrouther, D.A.; Bush, J.A.; Durani, P.; Taylor, L.; Skotny, G.; Mason, T.; Metcalfe, A.; O’Kane, S.; Ferguson, M.W. Avotermin for scar improvement following scar revision surgery: A randomized, double-blind, within-patient, placebo-controlled, phase II clinical trial. Plast. Reconstr. Surg. 2011, 128, 163-172. [CrossRef] [PubMed]

155. Occleston, N.L.; O’Kane, S.; Laverty, H.G.; Cooper, M.; Fairlamb, D.; Mason, T.; Bush, J.A.; Ferguson, M.W. Discovery and development of avotermin (recombinant human transforming growth factor $\beta 3$ ): A new class of prophylactic therapeutic for the improvement of scarring. Wound Repair Regen. 2011, 19 (Suppl. S1), s38-s48. [CrossRef] [PubMed]

156. Ferguson, M.W.; Duncan, J.; Bond, J.; Bush, J.; Durani, P.; So, K.; Taylor, L.; Chantrey, J.; Mason, T.; James, G.; et al. Prophylactic administration of avotermin for improvement of skin scarring: Three double-blind, placebo-controlled, phase I/II studies. Lancet 2009, 373, 1264-1274. [CrossRef]

157. Zhibo, X.; Miaobo, Z. Botulinum toxin type A affects cell cycle distribution of fibroblasts derived from hypertrophic scar. J. Plast. Reconstr. Aesthet. Surg. 2008, 61, 1128-1129. [CrossRef] [PubMed]

158. Xiao, Z.; Zhang, M.; Liu, Y.; Ren, L. Botulinum toxin type a inhibits connective tissue growth factor expression in fibroblasts derived from hypertrophic scar. Aesthet. Plast. Surg. 2011, 35, 802-807. [CrossRef] [PubMed]

159. Xiao, Z.; Zhang, F.; Lin, W.; Zhang, M.; Liu, Y. Effect of botulinum toxin type A on transforming growth factor $\beta 1$ in fibroblasts derived from hypertrophic scar: A preliminary report. Aesthet. Plast. Surg. 2010, 34, 424-427. [CrossRef] [PubMed]

160. Xiao, Z.; Zhang, F.; Cui, Z. Treatment of hypertrophic scars with intralesional botulinum toxin type A injections: A preliminary report. Aesthet. Plast. Surg. 2009, 33, 409-412. [CrossRef] [PubMed]

161. Gassner, H.G.; Sherris, D.A.; Otley, C.C. Treatment of facial wounds with botulinum toxin A improves cosmetic outcome in primates. Plast. Reconstr. Surg. 2000, 105, 1948-1953. [CrossRef] [PubMed]

162. Elhefnawy, A.M. Assessment of intralesional injection of botulinum toxin type A injection for hypertrophic scars. Indian J. Dermatol. Venereol. Leprol. 2016, 82, 279-283. [CrossRef] [PubMed]

163. Shaarawy, E.; Hegazy, R.A.; Abdel Hay, R.M. Intralesional botulinum toxin type A equally effective and better tolerated than intralesional steroid in the treatment of keloids: A randomized controlled trial. J. Cosmet. Dermatol. 2015, 14, 161-166. [CrossRef] [PubMed]

164. Zhibo, X.; Miaobo, Z. Intralesional botulinum toxin type A injection as a new treatment measure for keloids. Plast. Reconstr. Surg. 2009, 124, 275e-277e. [CrossRef] [PubMed] 
165. Jones, C.D.; Guiot, L.; Samy, M.; Gorman, M.; Tehrani, H. The Use of Chemotherapeutics for the Treatment of Keloid Scars. Dermatol. Rep. 2015, 7, 5880. [CrossRef] [PubMed]

166. Espana, A.; Solano, T.; Quintanilla, E. Bleomycin in the treatment of keloids and hypertrophic scars by multiple needle punctures. Dermatol. Surg. 2001, 27, 23-27. [PubMed]

167. Saray, Y.; Gulec, A.T. Treatment of keloids and hypertrophic scars with dermojet injections of bleomycin: A preliminary study. Int. J. Dermatol. 2005, 44, 777-784. [CrossRef] [PubMed]

168. Hendricks, T.; Martens, M.F.; Huyben, C.M.; Wobbes, T. Inhibition of basal and TGF $\beta$-induced fibroblast collagen synthesis by antineoplastic agents. Implications for wound healing. Br. J. Cancer 1993, 67, 545-550. [CrossRef] [PubMed]

169. Yeowell, H.N.; Marshall, M.K.; Walker, L.C.; Ha, V.; Pinnell, S.R. Regulation of lysyl oxidase mRNA in dermal fibroblasts from normal donors and patients with inherited connective tissue disorders. Arch. Biochem. Biophys. 1994, 308, 299-305. [CrossRef] [PubMed]

(C) 2018 by the authors. Licensee MDPI, Basel, Switzerland. This article is an open access article distributed under the terms and conditions of the Creative Commons Attribution (CC BY) license (http://creativecommons.org/licenses/by/4.0/). 